\title{
Thermal Pyrolysis of Used Lubricant and Cooking Oil Mixtures
}

\author{
Nazarudin $1,2,4^{*}$, S.P.Amalia², Afrida², Ulyarti ${ }^{3,4}$ \\ 1. Chemical Engineering Department, Faculty of Sain and Technology, Universitas Jambi, Jambi, Indonesia. \\ 2. Chemsitry Education Department, FKIP, Universitas Jambi, Jambi, Indonesia \\ 3. Department of Agriculture Product Technology, Faculty of Agriculture, University of Jambi, Indonesia \\ 4. Centre of Excellent in Bio-Geo Material, University of Jambi, Indonesia
}

\section{DOI: $\underline{10.29303 / j p p i p a . v 7 i 2.645}$}

\section{Article Info}

Received: February 20th, 2021

Revised: March 23th, 2021

Accepted: April 15th, 2021

\begin{abstract}
Pyrolysis is the one solution to recycle hydrocarbon-based waste material such as used lubricant and cooking oil. The aim of this research was to determine the effect of temperature and sample ratio on the liquid yields of a mixture of used lubricant and cooking oil. The semi batch reactor was used with a constant nitrogen flow rate of $5 \mathrm{~mL} / \mathrm{min}$. Three different ratios of sample mixture were applied in this experiment: 0.5:1, 1:1, and 1.5:1, and three different temperatures: $400^{\circ} \mathrm{C}, 450^{\circ} \mathrm{C}$, and $500^{\circ} \mathrm{C}$. The thermal pyrolysis of a mixture of used lubricant and cooking oil was deemed as the most effective pyrolysis to produce liquid fraction was obtained from reaction condition with the sample mixture ratio of $0.5: 1$ at $500{ }^{\circ} \mathrm{C}$. At this reaction condition, the liquid yield was $58.90 \%$ which consist of $64.12 \%$ were $C_{1}-C_{3}$ and $29.54 \%$ were $C_{5}-C_{15}$. Liquid fraction is predicted to increase as the temperature increase and the ratio of used lubricant to cooking oil decrease. When the ratio is increased, more gas fraction is produced.
\end{abstract}

Keywords: Used oils; and plastic waste; thermal pyrolysis

Citation: Nazarudin, N., Amalia, S., Afrida, A., \& Ulyarti, U. (2021). Thermal Pyrolysis of Used Lubricant and Cooking Oil Mixtures. Jurnal Penelitian Pendidikan IPA, 7(2), 218-223. doi:https://doi.org/10.29303/jppipa.v7i2.645

\section{Introduction}

Pyrolysis is the one solution to recycle waste materials like used cooking and lubricant oil into useful material such as fuel (Alfernando, Sarip, Anggraini, Nazarudin, 2019; Prabasari, Sarip, Rahmayani, Nazarudin, 2019; Fitriyanti, 2020), reduced sulphur content of fuel (Bhaskar, Uddin, Muto, Sakata, Omura, Kimura, Kawakami, 2004), surfactants (Sharma, Toor, Brandão, Pedersen, Rosendahl, 2021), plastisizer (Cai, Yue, Hao, \& Ma, 2020), and etc. At this method, waste material is heated at a high temperature and then break into new material. Pyrolysis can be carried out using catalyst (Alfernando et al., 2019; Prabasari et al., 2019; Fitriyanti, 2020) or without catalyst (Ayodeji and Oni, 2018; Alfernando, Nugraha, Prabasari, Haviz, Nazarudin, 2020). Due to a quite expensive catalyst, thermal cracking is more preferred despites its limitation in selectivity (Gaur, Mishra, Chowdhury, Baredar, Verma, 2020).

Santhoshkumar and Ramanathan (2010) reprocess used lubricant oil or waste engine oil (WEO) with pyrolysis method. Pyrolysis was done by heating the used lubricant oil at variated temperatures above the saturation temperature in the reactor with no oxygen. The result showed that the optimal temperature was at $500^{\circ} \mathrm{C}$. The compositions in a liquid product were $62.74 \%$ alkanes (paraffins), and the rests were ketones, alcohol, acids and others.

Bio-oil from thermal pyrolysis of used cooking oil have been produced at the laboratory scale. The result showed that the best condition to produce bio-oil $(52.34 \%)$ was at $550^{\circ} \mathrm{C}$ (Nazarudin, Prabasari, Ulyarti, Susilawati, Oktadio, 2020). Thermal pyrolysis of polyethylene terephthalate (PET) plastic waste and palm fibre mixtures were carried out at $400^{\circ} \mathrm{C}, 425^{\circ} \mathrm{C}$, $450^{\circ} \mathrm{C}$ in $10,20,30$ minutes reaction time in which the 
highest oil liquid product $(17 \%)$ was produced at $450^{\circ} \mathrm{C}$ for 10 minutes reaction (Nazarudin, Jayanti, Alfernando, Prabasari, Ulyarti, Sarip, 2020).

\section{Method}

The study was conducted by thermal pyrolysis in the semi-batch reactor (Figure 1). The samples and the liquid products of pyrolisis were analyzed by gas chromatography-mass spectrometry (GC-MS). There were three different ratios of samples 0.5:1, 1:1, and 1.5:1, and three different temperatures: $400^{\circ} \mathrm{C}, 450^{\circ} \mathrm{C}$, and $500^{\circ} \mathrm{C}$. The used cooking and lubricant oil were mixed and reacted with ratio and temperature as can bee seen in Table 1 . The nitrogen was flowed constantly $5 \mathrm{ml} / \mathrm{min}$ during 30 minutes reaction. The liquid products were taken every 5 minutes during the reaction.

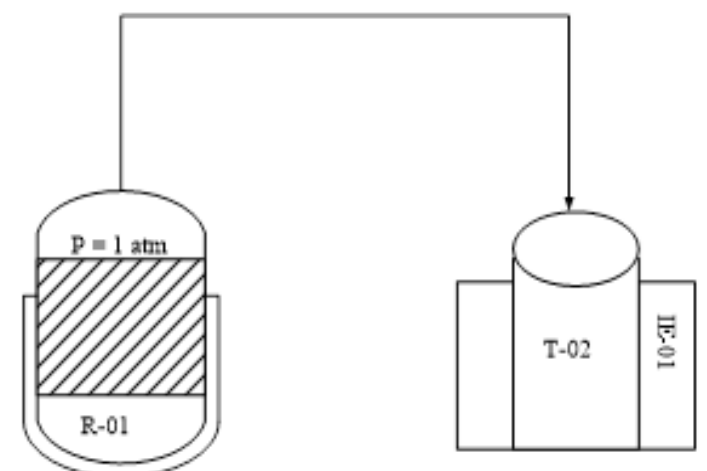

Figure 1. Schematic of Semi batch reactor (R-01: batch reactor, T-02: Oil Liquid Product storage tank, IE-01: Ice Trap)
Table 1. Thermal pyrolysis design (Gaspers, 1995)

\begin{tabular}{lllll}
\hline \multirow{2}{*}{$\begin{array}{l}\text { Reaction } \\
\text { number }\end{array}$} & $\mathrm{X}_{1}$ & \multicolumn{3}{c}{$\mathrm{X}_{2}$} \\
\cline { 2 - 5 } & Code & Ratio & Code & Temperature $\left({ }^{\circ} \mathrm{C}\right)$ \\
\hline 1 & -1 & $0.5: 1$ & -1 & 400 \\
2 & -1 & $0.5: 1$ & 1 & 500 \\
3 & 1 & $1.5: 1$ & -1 & 400 \\
4 & 1 & $1.5: 1$ & 1 & 500 \\
5 & 0 & $1: 1$ & 0 & 450 \\
6 & 0 & $1: 1$ & 0 & 450 \\
7 & 0 & $1: 1$ & 0 & 450 \\
\hline
\end{tabular}

Information:

$X_{1}=$ ratio of used lubricant and cooking oil (0.5:1, 1:1, 1.5:1). $0.5=5$ gram; $1=10$ gram; $1.5=15$ gram

$\mathrm{X}_{2}=$ temperature $\left({ }^{\circ} \mathrm{C}\right)(400,450,500)$

\section{Result and Discussion}

\section{Composition of waste material}

The composition of waste material were examined using GC-MS and the results are presented in Table 2 and Table 3.

Table 2. The composition of used lubrican oil as shown by GC-MS

\begin{tabular}{|c|c|c|c|c|c|c|}
\hline No. & RT & $\%$ Area & SI & Compounds & Formula & MW \\
\hline \multirow[t]{2}{*}{1.} & 1.98 & 2.45 & 97 & Carbamic acid & $\mathrm{CH}_{3} \mathrm{NO}_{2}$ & 61 \\
\hline & & & & Nitrous oxide & $\mathrm{N}_{2} \mathrm{O}$ & 44 \\
\hline 2. & 2.05 & 60.59 & 96 & 1-Propene, 2-methyl & $\mathrm{C}_{4} \mathrm{H}_{8}$ & 56 \\
\hline 3. & 23.61 & 5.72 & 80 & 3,5-Diisopropyl-1,2,4 trithiolane & $\mathrm{C}_{8} \mathrm{H}_{16} \mathrm{~S}_{3}$ & 208 \\
\hline \multirow[t]{3}{*}{4.} & 32.57 & 1.80 & 95 & Eicosane & $\mathrm{C}_{20} \mathrm{H}_{42}$ & 282 \\
\hline & & & & Heneicosane & $\mathrm{C}_{21} \mathrm{H}_{44}$ & 296 \\
\hline & & & & Tricosane & $\mathrm{C}_{23} \mathrm{H}_{48}$ & 324 \\
\hline \multirow[t]{3}{*}{5.} & 34.70 & 2.63 & 96 & Heneicosane & $\mathrm{C}_{21} \mathrm{H}_{44}$ & 296 \\
\hline & & & & Eicosane & $\mathrm{C}_{20} \mathrm{H}_{42}$ & 282 \\
\hline & & & & Tricosane & $\mathrm{C}_{23} \mathrm{H}_{48}$ & 324 \\
\hline \multirow[t]{3}{*}{6.} & 36.73 & 3.58 & 97 & Tricosane & $\mathrm{C}_{23} \mathrm{H}_{48}$ & 324 \\
\hline & & & & Eicosane & $\mathrm{C}_{20} \mathrm{H}_{42}$ & 282 \\
\hline & & & & Heptadecane & $\mathrm{C}_{17} \mathrm{H}_{36}$ & 240 \\
\hline \multirow[t]{3}{*}{7.} & 38.67 & 5.02 & 97 & Octadecane & $\mathrm{C}_{18} \mathrm{H}_{38}$ & 254 \\
\hline & & & & Eicosane & $\mathrm{C}_{20} \mathrm{H}_{42}$ & 282 \\
\hline & & & & Tricosane & $\mathrm{C}_{23} \mathrm{H}_{48}$ & 324 \\
\hline \multirow[t]{3}{*}{8.} & 40.54 & 5.52 & 97 & Tricosane & $\mathrm{C}_{23} \mathrm{H}_{48}$ & 324 \\
\hline & & & & Eicosane & $\mathrm{C}_{20} \mathrm{H}_{42}$ & 282 \\
\hline & & & & Octadecane & $\mathrm{C}_{18} \mathrm{H}_{38}$ & 254 \\
\hline \multirow[t]{3}{*}{9.} & 42.32 & 5.22 & 97 & Tricosane & $\mathrm{C}_{23} \mathrm{H}_{48}$ & 324 \\
\hline & & & & Eicosane & $\mathrm{C}_{20} \mathrm{H}_{42}$ & 282 \\
\hline & & & & Pentacosane & $\mathrm{C}_{25} \mathrm{H}_{52}$ & 352 \\
\hline
\end{tabular}




\begin{tabular}{|c|c|c|c|c|c|c|}
\hline No. & RT & $\%$ Area & SI & Compounds & Formula & MW \\
\hline & & & & Octadecane & $\mathrm{C}_{18} \mathrm{H}_{38}$ & 254 \\
\hline \multirow[t]{2}{*}{10.} & 44.03 & 4.42 & 97 & Tricosane & $\mathrm{C}_{23} \mathrm{H}_{48}$ & 324 \\
\hline & & & & Octadecane & $\mathrm{C}_{18} \mathrm{H}_{38}$ & 254 \\
\hline \multirow[t]{3}{*}{11.} & 45.68 & 3.05 & 95 & Tricosane & $\mathrm{C}_{23} \mathrm{H}_{48}$ & 324 \\
\hline & & & & Octadecane & $\mathrm{C}_{18} \mathrm{H}_{38}$ & 254 \\
\hline & & & & Pentacosane & $\mathrm{C}_{25} \mathrm{H}_{52}$ & 352 \\
\hline
\end{tabular}

Table 3. The composition of used cooking oil as shown by GC-MS

\begin{tabular}{|c|c|c|c|c|c|c|}
\hline No & RT & $\%$ Area & SI & Compounds & $\begin{array}{l}\text { Formula } \\
\text { Molecules }\end{array}$ & $\begin{array}{l}\text { Molecular } \\
\text { Weight }\end{array}$ \\
\hline \multirow[t]{3}{*}{1.} & 39.92 & 20.95 & 90 & 13-Oxabicyclo[10.1.0]tridecane & $\mathrm{C}_{12} \mathrm{H}_{22} \mathrm{O}$ & 182 \\
\hline & & & & Oleic Acid & $\mathrm{C}_{18} \mathrm{H}_{34} \mathrm{O}_{2}$ & 282 \\
\hline & & & 89 & Cis-7-tetradecene-1-ol & $\mathrm{C}_{14} \mathrm{H}_{28} \mathrm{O}$ & 212 \\
\hline \multirow[t]{4}{*}{2.} & 41.75 & 37.00 & 86 & 1,3-Dipalmitoylglycerol & $\mathrm{C}_{35} \mathrm{H}_{68} \mathrm{O}_{5}$ & 569 \\
\hline & & & 85 & $\begin{array}{l}\text { 3-\{[(2-Aminoethoxy)(hydroxy)phosphoryl }] \text { oxy }\}-2- \\
\text { (palmitoyloxy)propyl palmitate }\end{array}$ & $\mathrm{C}_{37} \mathrm{H}_{74} \mathrm{NO}_{8} \mathrm{P}$ & 691 \\
\hline & & & 84 & Glyceryl 1,3-distearate & $\mathrm{C}_{39} \mathrm{H}_{76} \mathrm{O}_{5}$ & 624 \\
\hline & & & & Docosanoic acid & $\mathrm{C}_{22} \mathrm{H}_{44} \mathrm{O}_{2}$ & 340 \\
\hline \multirow[t]{4}{*}{3.} & 44.57 & 7.88 & 90 & (Z)6,(Z)9-Pentadecadien-1-ol & $\mathrm{C}_{15} \mathrm{H}_{28} \mathrm{O}$ & 224 \\
\hline & & & 87 & Cyclododecyne & $\mathrm{C}_{12} \mathrm{H}_{20}$ & 164 \\
\hline & & & & 1,E-6,Z-11-Hexadecatriene & $\mathrm{C}_{16} \mathrm{H}_{28}$ & 220 \\
\hline & & & & 1,E-11,Z-13-Octadecatriene & $\mathrm{C}_{18} \mathrm{H}_{32}$ & 248 \\
\hline \multirow[t]{3}{*}{4.} & 44.72 & 34.17 & 88 & 1,3-Diolein & $\mathrm{C}_{39} \mathrm{H}_{72} \mathrm{O}_{5}$ & 621 \\
\hline & & & 87 & 9-Octadecen-1-ol,(Z) & $\mathrm{C}_{18} \mathrm{H}_{36} \mathrm{O}$ & 268 \\
\hline & & & 86 & 13-octadecenal, $(Z)$ & $\mathrm{C}_{18} \mathrm{H}_{34} \mathrm{O}$ & 266 \\
\hline
\end{tabular}

Thermal pyrolysis of mixture of used cooking and lubricant oil

There were three types of products produced by thermal pyrolysis of a mixture of used cooking oil and used lubricant oil. The products were liquid, gas, and coke with the liquid was the main product in this reaction.

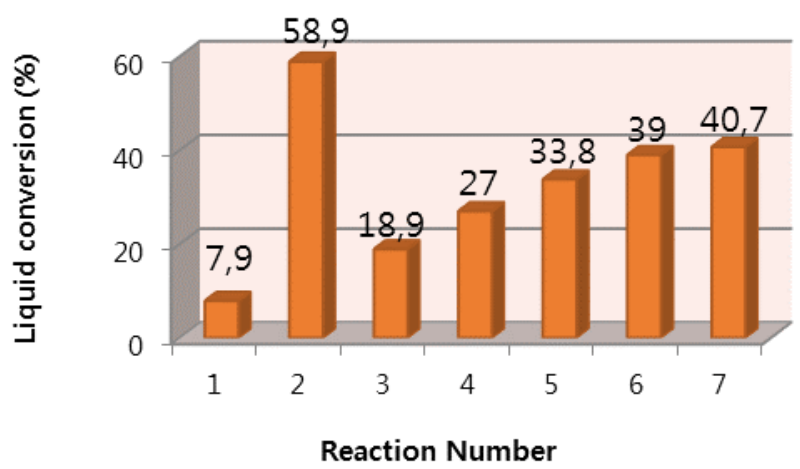

Figure 2 The liquid yields for thermal pyrolysis of mixture of used lubricant and cooking oil mixture

The liquid yields are the mass ratio of liquid fraction and the total sample mixture (used lubricant and cooking oil). Figure 2 shows that the highest liquid yields for thermal pyrolysis of a mixture of used cooking oil and used lubricant oil was at reaction number 2 (ratio $0.5: 1$, temperature $500^{\circ} \mathrm{C}$ ). The liquid yield at this condition was $58.9 \%$. The yield for liquid fraction in this experiment is much lower than previously reported (Trabelsi, Zaafouri, Baghdadi, Naoui, Ouerghi, 2018) who reported 80\% liquid yields over thermal pyrolysis of used cooking oil. Besides the difference in the feed, the high amount of liquid yields is due to a much higher temperature used in the pyrolysis $800^{\circ} \mathrm{C}$ (Trabelsi et al., 2018).

The GC-MS analysis shows that the liquid fraction (reaction number 2) of thermal pyrolysis of the mixture consist of 19 components as shown in Table 4. Thermal pyrolysis has cracked the $C_{1}$ to $C_{39}$ components in the used lubricant and cooking oil mixtures to produce $\mathrm{C}_{2}-\mathrm{C}_{30}$ hydrocarbon compounds in the liquid fraction which is categorized as diesel-like fuel. Among these products in the liquid fraction, $64.12 \%$ were $C_{1}-C_{3}$ and $29.54 \%$ were $C_{5}-C_{15}$. The cumulative of liquid yields for thermal pyrolysis used cooking and lubricant oil mixtures can bee seen in Figure 4. This graphs shows the progress of liquid production during pyrolisis and that the liquid production at reaction number 2 is increasing in quite constant rate.

The gas conversion for thermal pyrolysis of used lubricant and cooking oil mixture is shown in Figure 4. This result is higher than thermal pyrolysis of waste lubricant oil at similar temperature reported previously (Fuentes, Font, Gómez-Rico, Martín-Gullón, 2007). Controlling the ratio of used oil may help researcher to obtain what product is more preferred, either liquid or gas. The other study of co-pyrolysis was reported by Phetyim, Pivsa-Art. where used lubricant oil and 
mixed plastic waste were cracked to produce a diesellike fuel (Phetyim \& Pivsa-Art, 2018).

The coke conversion for thermal pyrolysis of used lubricant and cooking oil mixture for every reaction number is shown in Figure 5. Temperature plays an important role in the completeness of the thermal pyrolysis reaction. The lowest ttemperatures applied in this experiment produced the highest coke production. The higher the temperature, the lower the Cokes conversion.

Respons surface analysis for thermal pyrolysis of used lubricant and cooking oil

The respons surface analysis was applied to obtain the optimum reaction condition for thermal pyrolysis of used lubricant and cooking oil. As seen in
Figure 5-7, all graphs in the surface plots are flats without any indication can reach a maximum or minimum peak. This is due to the remote experimental design region. From these graphs, it can be seen that the temperature should be higher than $500^{\circ} \mathrm{C}$ and the ratio should be lower than $0.5: 1$ in order to obtain maximum liquid fraction (Figure 6). In other words, if liquid fraction is preferred, used lubricant oil oil should be used far less than used cooking oil. However, more used lubricant oil should be used more if gas fraction is preferred (Figure 6). Since coke is the product that should be minimised, lower ratio is more preferred while no agreement on temperature can be made (Figure 7).

Table 4. The composition of liquid fraction (reaction number 2 ) from thermal pyrolisis of used lubricant and cooking oil mixture as shown by GC-MS

\begin{tabular}{|c|c|c|c|c|c|c|}
\hline No. & RT & $\%$ Area & SI & Compounds & $\begin{array}{l}\text { Formula } \\
\text { Molecules }\end{array}$ & $\begin{array}{l}\text { Molecular } \\
\text { Weight }\end{array}$ \\
\hline \multirow[t]{3}{*}{1.} & 1.97 & 49.65 & 92 & Oxalid acid & $\mathrm{C}_{2} \mathrm{H}_{2} \mathrm{O}_{4}$ & 90 \\
\hline & & & & Carbamic acid & $\mathrm{CH}_{3} \mathrm{NO}_{2}$ & 61 \\
\hline & & & & 1,1-dibromo-2-chloro-2-fluoro & $\mathrm{C}_{3} \mathrm{H}_{2} \mathrm{Br}_{2} \mathrm{ClF}$ & 250 \\
\hline \multirow[t]{5}{*}{2.} & 2.03 & 2.17 & 25 & 4-phenoxy-,trimethylsily ester & $\mathrm{C}_{13} \mathrm{H}_{20} \mathrm{O}_{3} \mathrm{Si}$ & 252 \\
\hline & & & 24 & 3,4-Dimethoxyphenylpentanoic acid & $\mathrm{C}_{16} \mathrm{H}_{26} \mathrm{O}_{4} \mathrm{Si}$ & 310 \\
\hline & & & 23 & 4,4-Dinitro-6,6-ethylenedioxy-4,5,6,7-benzofuroxane & $\mathrm{C}_{8} \mathrm{H}_{8} \mathrm{~N}_{4} \mathrm{O}_{8}$ & 288 \\
\hline & & & & Benzo cazepin,7,8,9-trimethoxy & $\mathrm{C}_{13} \mathrm{H}_{19} \mathrm{NO}_{3}$ & 237 \\
\hline & & & 22 & bixindial & $\mathrm{C}_{24} \mathrm{H}_{28} \mathrm{O}_{2}$ & 348 \\
\hline \multirow[t]{4}{*}{3.} & 2.15 & 23.45 & 67 & Hexaborane-12 & $\mathrm{B}_{6} \mathrm{H}_{12}$ & 78 \\
\hline & & & 60 & 1,2-tetramethylenediborane & $\mathrm{C}_{4} \mathrm{H}_{12} \mathrm{~B}_{2}$ & 82 \\
\hline & & & 59 & Nickel 1-amino-1,9-diisothiocipno-4,8-di-azaudecamine & $\mathrm{C}_{11} \mathrm{H}_{22} \mathrm{~N}_{6} \mathrm{NIS}_{2}$ & 360 \\
\hline & & & 58 & Trans-2,3-Epoxyoctane & $\mathrm{C}_{8} \mathrm{H}_{16} \mathrm{O}$ & 128 \\
\hline 4. & 2.38 & 4.10 & 80 & Furan,2-methyl & $\mathrm{C}_{5} \mathrm{H}_{6} \mathrm{O}$ & 82 \\
\hline 5. & 2.53 & 11.20 & 96 & Acetic Acid & $\mathrm{C}_{2} \mathrm{H}_{4} \mathrm{O}_{2}$ & 60 \\
\hline \multirow[t]{2}{*}{6.} & 2.68 & 3.27 & 95 & 2-Propanone, 1-hydroxy & $\mathrm{C}_{3} \mathrm{H}_{6} \mathrm{O}_{2}$ & 74 \\
\hline & & & 94 & Acetaldehyde & $\mathrm{C}_{2} \mathrm{H}_{4} \mathrm{O}$ & 44 \\
\hline 7. & 3.11 & 0.94 & 81 & 2-Propenoic Acid & $\mathrm{C}_{3} \mathrm{H}_{4} \mathrm{O}_{2}$ & 72 \\
\hline 8. & 4.22 & 1.46 & 85 & 1,2-butadiene,3-methoxy & $\mathrm{C}_{5} \mathrm{H}_{8} \mathrm{O}$ & 84 \\
\hline 9. & 6.51 & 0.25 & 95 & 2,5-Hexanedione & $\mathrm{C}_{6} \mathrm{H}_{10} \mathrm{O}_{2}$ & 114 \\
\hline 10. & 7.93 & 0.28 & 85 & 2-Pentanone, 3-methyl & $\mathrm{C}_{6} \mathrm{H}_{12} \mathrm{O}$ & 100 \\
\hline \multirow[t]{3}{*}{11.} & 36.64 & 0.39 & 92 & Heneicosane & $\mathrm{C}_{21} \mathrm{H}_{44}$ & 296 \\
\hline & & & & Pentacosane & $\mathrm{C}_{25} \mathrm{H}_{52}$ & 352 \\
\hline & & & & Docosane & $\mathrm{C}_{22} \mathrm{H}_{46}$ & 310 \\
\hline \multirow[t]{3}{*}{12.} & 38.58 & 0.45 & 94 & Tricosane & $\mathrm{C}_{23} \mathrm{H}_{48}$ & 324 \\
\hline & & & & Pentacosane & $\mathrm{C}_{25} \mathrm{H}_{52}$ & 352 \\
\hline & & & & Eicosane & $\mathrm{C}_{20} \mathrm{H}_{42}$ & 282 \\
\hline \multirow[t]{3}{*}{13.} & 40.44 & 0.55 & 94 & Tricosane & $\mathrm{C}_{23} \mathrm{H}_{48}$ & 324 \\
\hline & & & & Octadecane, 2-methyl & $\mathrm{C}_{19} \mathrm{H}_{40}$ & 268 \\
\hline & & & & triacontane & $\mathrm{C}_{30} \mathrm{H}_{62}$ & 422 \\
\hline \multirow[t]{3}{*}{14.} & 41.35 & 0.23 & 83 & Germacrane & $\mathrm{C}_{15} \mathrm{H}_{30}$ & 210 \\
\hline & & & & Tridecanol & $\mathrm{C}_{13} \mathrm{H}_{28} \mathrm{O}$ & 200 \\
\hline & & & 82 & Cyclopentane -heneicosyl & $\mathrm{C}_{26} \mathrm{H}_{52}$ & 364 \\
\hline 15. & 41.65 & 0.44 & 84 & Docosanoic Acid & $\mathrm{C}_{22} \mathrm{H}_{44} \mathrm{O}_{2}$ & 340 \\
\hline \multirow[t]{2}{*}{16.} & 42.21 & 0.33 & 92 & Tricosane & $\mathrm{C}_{23} \mathrm{H}_{48}$ & 324 \\
\hline & & & & Eicosane & $\mathrm{C}_{20} \mathrm{H}_{42}$ & 282 \\
\hline \multirow[t]{3}{*}{17.} & 42.84 & 0.24 & 80 & Octadecane, 1-chloro & $\mathrm{C}_{18} \mathrm{H}_{37} \mathrm{Cl}$ & 288 \\
\hline & & & & 1-Hexacosanol & $\mathrm{C}_{26} \mathrm{H}_{54} \mathrm{O}$ & 382 \\
\hline & & & & Hexadecane,1-chloro & $\mathrm{C}_{16} \mathrm{H}_{33} \mathrm{Cl}$ & 260 \\
\hline 18. & 44.64 & 0.36 & 82 & 9-octadecenal & $\mathrm{C}_{18} \mathrm{H}_{34} \mathrm{O}$ & 266 \\
\hline 19. & 45.71 & 0.25 & 81 & Di-n-octyl phthalate & $\mathrm{C}_{24} \mathrm{H}_{38} \mathrm{O}_{4}$ & 390 \\
\hline
\end{tabular}




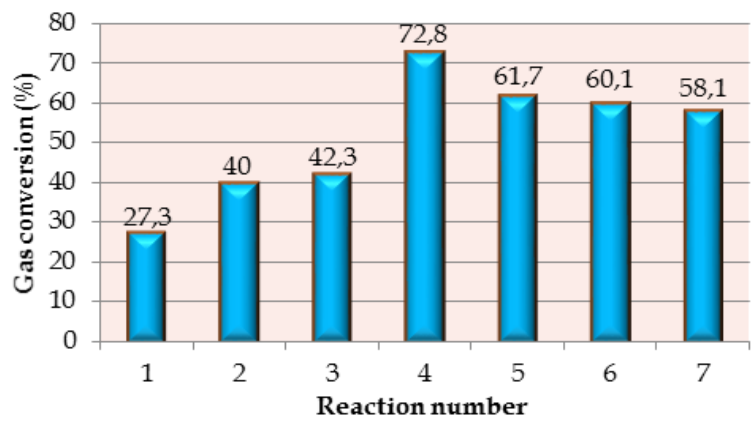

Figure 3. Gas yields for thermal pyrolysis of used lubricant and cooking oil mixture

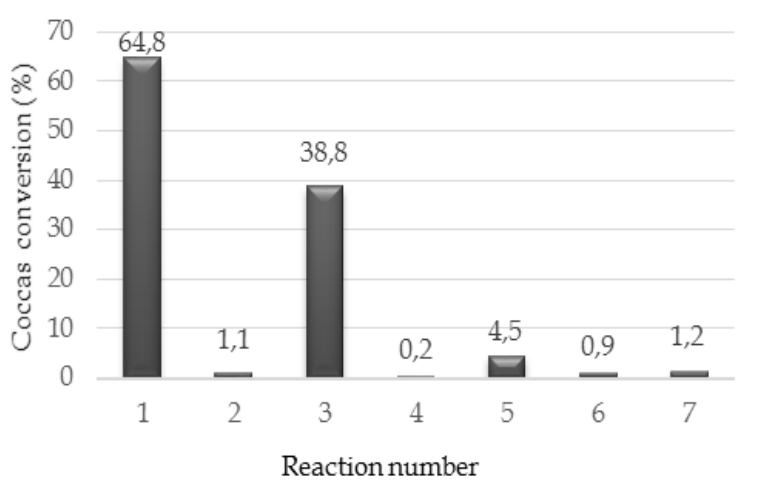

Figure 4. Coke yields for thermal pyrolysis of used lubricant and cooking oil mixture

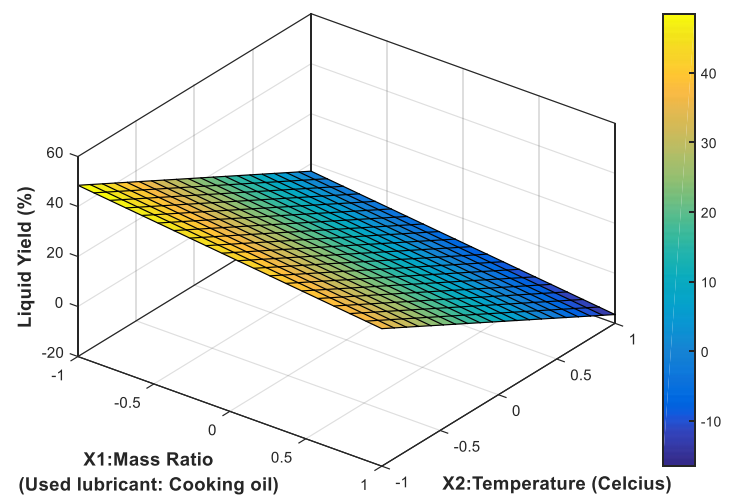

Figure 5. Surface plots of liquid yields on thermal pyrolysis of used lubricant and cooking oil mixture

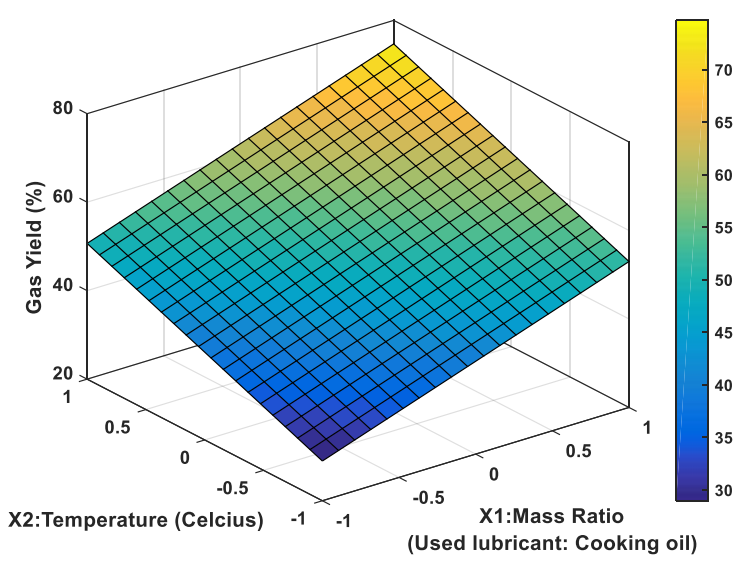

Figure 6. Surface plots of gas yields on thermal pyrolysis of used lubricant and cooking oil mixture

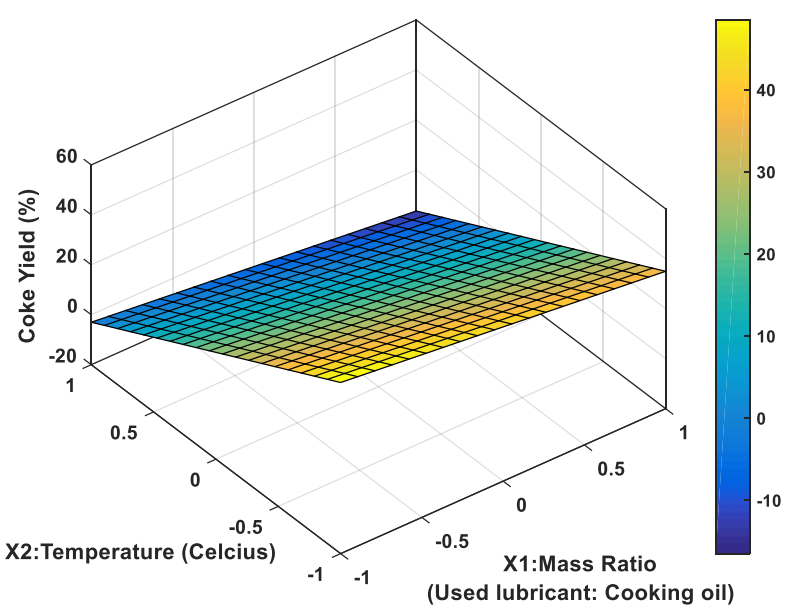

Figure 7. Surface plots of coke yields on thermal pyrolysis of used lubricant and cooking oil mixture

\section{Conclusion}

Thermal pyrolysis of a mixture of used lubricant and cooking oil mixture produce diesel like fuel. The most effective pyrolysis of a mixture of used cooking oil: used lubricant oil is in ratio $0.5: 1$ and temperature $500^{\circ} \mathrm{C}$. The surface plots of thermal pyrolysis of used lubricant and cooking oil mixture showed that the optimum condition for liquid and gas yields was beyond the experimental design applied in this experiment.

\section{Acknowledgements}

Thanks to DIKTI for funding this research through hibah Penerapan Ipteks 2015 and Energy and Nano 
Material Research Centre, University of Jambi for experimental analysis.

\section{References}

Alfernando, O., Sarip, R., Anggraini, T., Nazarudin, N. (2019). Catalytic Cracking of Methyl Ester from Used Cooking Oil with Ni-Ion-Exchanged ZSM-5 Catalyst. Makara J. Sci. 23, 169-178. https://doi.org/10.7454/mss.v23i4.11509

Alfernando,O., Nugraha, F. D. A., Prabasari I. G.,3, Haviz, M.,Nazarudin (2020), Thermal Cracking of Polyethylene Terepthalate (PET) Plastic Waste J. Phys. Conf. Ser. 1567.

https://doi:10.1088/1742-6596/1567/2/022023

Ayodeji,S.O., Oni,T.O., (2018).Thermal pyrolysis production of liquid fuel from a mixture of polyethylene terephthalate and polystyrene. Heat Transfer - Asian Res. 2019;1-15. https://doi.org/10.1002/htj.21450

Ben Hassen Trabelsi, A., Zaafouri, K., Baghdadi, W., Naoui, S., Ouerghi, A. (2018). Second generation biofuels production from waste cooking oil via pyrolysis process. Renew. Energy 126, 888-896. https://doi.org/10.1016/j.renene.2018.04.002

Bhaskar, T., Uddin, M.A., Muto, A., Sakata, Y., Omura, Y., Kimura, K., Kawakami, Y. (2004). Recycling of waste lubricant oil into chemical feedstock or fuel oil over supported iron oxide catalysts. Fuel 83, 9-15. https://doi.org/10.1016/S00162361(03)00216-3

Cai, Deng-liang, Xiu Yue, Bin Hao, and Peng-cheng Ma. (2020). "A Sustainable Poly (Vinyl Chloride) Plasticizer Derivated from Waste Cooking Oil." Journal of Cleaner Production 274:122781. https://doi.org/10.1016/j.jclepro.2020.122781

Fitriyanti, R. (2020). Produksi Bahan Bakar Cair Hasil Pirolisis Minyak Pelumas Bekas Pertambangan Batubara Menggunakan Katalis Zeolite. J. Redoks 5, 1. https://doi.org/10.31851/redoks.v5i1.3958

Fuentes, M.J., Font, R., Gómez-Rico, M.F., MartínGullón, I. (2007). Pyrolysis and combustion of waste lubricant oil from diesel cars: Decomposition and pollutants. J. Anal. Appl. Pyrolysis 79, 215-226. https://doi.org/10.1016/j.jaap.2006.12.004

Gaur, A., Mishra, S., Chowdhury, S., Baredar, P., Verma, P. (2020). A review on factor affecting biodiesel production from waste cooking oil: An Indian perspective. Mater. Today Proc. https://doi.org/10.1016/j.matpr.2020.09.432

Pheyim,N., Pivsa-Art, S. (2018) Prototype Co-Pyrolysis of Used Lubricant Oil and Mixed Plastic Waste to
Produce a Diesel-Like Fuel. Energies 11, 2973 http://doi:10.3390/en11112973

Myers, R.H.,Montgomery,D.C., Anderson-Cook,C.M., (2016) Response surface methodology : process and product optimization using designed experiments, 4th Edition, Wiley series in probability and statistics

Nazarudin, Prabasari, I.G., Ulyarti, Susilawati, Oktadio, A. (2020). Catalytic cracking of used cooking oil using Chromium impregnated charcoal (Crcharcoal) catalyst. J. Phys. Conf. Ser. 1567.

Nazarudin, Jayanti,N., Alfernando,O.,Prabasari, I.G., Ulyarti, Sarip,R. (2020) Catalytic cracking of polyethylene terephthalate (PET) plastic waste and palm fibre mixtures using Ni-USY zeolite catalyst J. Phys. Conf. Ser. 1567.

https://doi:10.1088/1742-6596/1567/2/022034

Prabasari, I.G., Sarip, R., Rahmayani, S., Nazarudin (2019). Catalytic Cracking of Used Cooking Oil Using Cobalt-impregnated Carbon Catalysts. $\begin{array}{llll}\text { Makara } & \text { J. } & \text { Sci. }\end{array}$ https://doi.org/10.7454/mss.v23i3.11264

Santhoshkumar,A. and Ramanathan,A. (2020) Recycling of waste engine oil through pyrolysis process for the production of diesel like fuel and its uses in diesel engine. Energy 197 (2020) 117240 http://doi.org/10.1016/j.energy.2020.117240

Sharma, K., Toor, S.S., Brandão, J., Pedersen, T.H., Rosendahl, L.A. (2021). Optimized conversion of waste cooking oil into ecofriendly bio-based polymeric surfactant- A solution for enhanced oil recovery and green fuel compatibility. Journal of Cleaner Production, 294. https://doi.org/10.1016/j.jclepro.2021.126214 